\title{
Joint pausiness in parallel spike trains
}

\author{
Matthias Gärtner ${ }^{1 *}$, Sevil Duvarci ${ }^{2}$, Jochen Roeper ${ }^{2}$, Gaby Schneider ${ }^{1}$ \\ From 24th Annual Computational Neuroscience Meeting: CNS*2015 \\ Prague, Czech Republic. 18-23 July 2015
}

So-called 'pauses', i.e., periods with surprisingly few spikes, have recently gained increasing attention in the analysis of parallel spike trains of dopaminergic (DA) and Purkinje cells, in particular concerning simultaneity of pausing activity. The analysis of simultaneous pauses is usually based on the pauses identified in the separate spike trains. As a consequence, such techniques can suffer from the local definition of a pause within one spike train and can thus fail to identify joint pauses across spike trains that are easily detectable by eye. In addition, they crucially depend on the algorithm used for pause detection.

In order to tackle this problem, we present a new statistical method for the detection of synchronous pauses that focuses on typical characteristics of time periods showing synchronous pauses in parallel spike trains, and introduce a new measure for synchronous pausiness in parallel spike trains. We apply the technique to a data set of parallel DA neurons recorded from the VTA in freely moving mice. Interestingly, pausiness can be significantly increased in parallel spike trains as compared to individual processes or processes shifted by small time lags. This observation is robust and practically independent from the algorithm used for pause detection.
doi:10.1186/1471-2202-16-S1-P218

Cite this article as: Gärtner et al:: Joint pausiness in parallel spike trains.

BMC Neuroscience 2015 16(Suppl 1):P218.

\section{Acknowledgements}

This work was supported by the Priority Program 1665 of the DFG (SD, MG, $J R, G S)$ and by the German Federal Ministry of Education and Research (BMBF, Funding number: 01ZX1404B; GS).

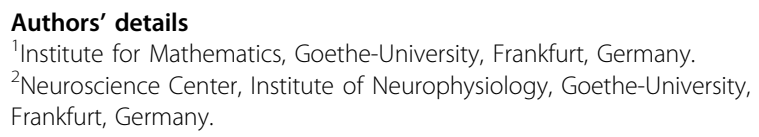

Published: 18 December 2015

* Correspondence: gaertner@math.uni-frankfurt.de

${ }^{1}$ Institute for Mathematics, Goethe-University, Frankfurt, Germany

Full list of author information is available at the end of the article
Submit your next manuscript to BioMed Central and take full advantage of:

- Convenient online submission

- Thorough peer review

- No space constraints or color figure charges

- Immediate publication on acceptance

- Inclusion in PubMed, CAS, Scopus and Google Scholar

- Research which is freely available for redistribution

\section{() Biomed Central}

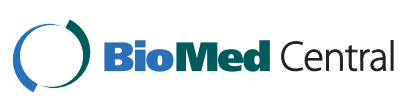

(c) 2015 Gärtner et al. This is an Open Access article distributed under the terms of the Creative Commons Attribution License (http:// creativecommons.org/licenses/by/4.0), which permits unrestricted use, distribution, and reproduction in any medium, provided the original work is properly cited. The Creative Commons Public Domain Dedication waiver (http://creativecommons.org/publicdomain/ zero/1.0/) applies to the data made available in this article, unless otherwise stated. 